\title{
SERPINE1 wt Allele
}

National Cancer Institute

\section{Source}

National Cancer Institute. SERPINE1 wt Allele. NCI Thesaurus. Code C51407.

Human SERPINE1 wild-type allele is located within 7q21.3-q22 and is approximately $12 \mathrm{~kb}$ in length. This allele, which encodes plasminogen activator inhibitor 1 protein, plays a role in preventing the generation of plasmin. Defects in the SERPINE1 gene cause PAI-1 deficiency. Overexpression of this gene is associated with thrombophilia. 